\title{
VITALITY OF LANGUAGE AND CULTURE IN MALAYSIAN WEDDING CARDS: A MULTIETHNIC PERSPECTIVE
}

\author{
Siti Rohana Mohd Thani and Kuang Ching Hei \\ University of Malaya
}

\begin{abstract}
The way language is used within a certain community reflects the culture of its users but is it possible to accommodate the culture of others when different communities live within one country as citizens? This paper examined thirty Malaysian wedding cards gathered from the three dominant ethnic groups of Malay, Chinese and Indian. It focussed on the vitality of language and culture presented in current day wedding cards issued by modern day couples, that is, from the year 2000 onwards. Data extracted for analysis comprised the language printed on the cards followed by the symbolic and cultural features noted on and within the cards. Leech's (1981) framework of making meanings from printed language was applied. Findings suggest that current day wedding cards of the three ethnic communities have adapted to modernisation in terms of design, colour and information. However, symbolic language and traditional and cultural features reflecting each of the respective community were still prevalent. The findings imply that despite the advancement of technology and globalisation, Malaysia's diverse ethnic groups remained faithful to their cultures with each group retaining and promoting its respective symbolic features and cultural identity. This indicates that one's ethnic identity and culture are important particularly when expressed through wedding cards. Our claim is confined to the analysis of a small portion of wedding cards, hence, a more extensive study may be necessary to verify this claim.
\end{abstract}

KEYWORDS: CULTURE, IDENTITY, TRADITION, SYMBOLIC FEATURES, WEDDING CARDS

\section{Introduction}

The meaning of life concerns birth and death. In between life, there are weddings. Weddings are occasions where two people exchange vows or choose to legally become committed to each other as husbands and wives for the purpose of starting a family, be together or just to share their lives. Some marriages involve simple procedures while other marriages involve complicated measures of permission seeking processes, date selecting rituals, cleansing ceremonies as well as other cultural preparations and procedures. The choice of adhering or not adhering to all these rituals is of course, up to the individual. However, in many of the observations made of couples arranging to get married, many, especially those marrying for the first time, want to have their dream weddings, which tend to include going through the intricate rituals according to their respective cultures and not just for the fun and novelty of it. In some cases, couples want to go through all these rituals because of the belief attached to the rituals. Most couples, particularly those in the Asian context, would want to weather anything that comes their way for their wedding because it is believed that such rituals would bring about a blissful and harmonious start when the couples share their lives together. Moreover, when a wedding is conducted with such intricacy, the meanings attached to these weddings become more meaningful and sentimental too. Weddings are considered happy occasions because they bring joy and 


\section{VITALITY OF LANGUAGE AND CULTURE IN MALAYSIAN WEDDING CARDS: A MULTIETHNIC PERSPECTIVE}

happiness to the respective families when their children are united as a couple. This is why in the Chinese culture, weddings are symbolised by the double happiness character of "Xi".

In the Malaysian context, most families believe that conducting the wedding rituals according to the norms of their respective community cannot be neglected or forsaken because the harmony and happiness of the couple's future lies in how those rituals are performed. Whether Malay, Chinese or Indian, the belief is almost the same. Likewise, for the Malaysians, selecting a good day, time, place for the wedding is equally important especially for the Chinese. Since weddings are joyous and happy occasions, they have to be shared with relatives, friends and acquaintances hence, issuing wedding cards is important as a means of making the announcement. Although wedding cards may be mere objects, many Malaysians also place certain level of importance on the design of the wedding cards as the card has to bear all the right information and connotation.

Nonetheless, the design of wedding cards in the Malaysian context would vary according to ethnic backgrounds, religion and regional locations. In the past, wedding cards did not use to be in existence because wedding invitations were often extended through words of mouth. Weddings held in villages would be the talk of the village as everyone in the village is involved with the weddings. Historically, villagers living in the same place would collaborate in organising the wedding a few days earlier. They would all be given duties to perform such as cooking and serving duties, preparing brides and grooms for the ceremony, attending to guests and decoration or setting up and decorating the venues. In Malay, this is called "gotong royong". The same activities would also occur for the Chinese community as well as the Indian community within the Malaysian context. However, as time passes, things became modernised and so weddings became organised and planned by 'wedding planners'. All these services offered by the wedding planner would be paid for so, the choice of every detail of the wedding would be up to the respective couples and their families. However, it has not been ascertained as to who makes the decision on how the wedding card is designed among the couples of the three ethnic groups. However, taking modernity and technology into consideration, it would be the young couples who would be given the choice of making the decision on how their wedding cards are designed. Nonetheless, with the Malaysian society being a collectivistic one, it is quite possible that it is the head of the family who decides on the design of the wedding card with some advice thrown in by the wedding card designers. Even within the same ethnic community among Malaysians, wedding cards can differ in terms of design, outline, format, colour and even visuals. Although there are documentations of Malaysian weddings which discuss how these weddings are organised or what each of the procedures mean, there are no documentations denoting what the wedding cards from the three ethnic groups of Malaysia represent. Consequently, it could not be ascertained as to what would be the most important element to feature in one's wedding card and what would be the significance of these elements. The analysis of the wedding cards in terms of symbolic elements in this paper was thus based on the input of cultural experts who have much experience.

\section{Aim}

This paper examines the differences in language and culture noted in the wedding cards issued by the three dominant ethnic groups of Malaysia: Malay, Chinese and Indian. Specifically, it aims to determine if the vitality of language and culture prevails in the respective wedding cards and if so, to what extent? In that regard, this paper aims to answer two research questions:

1. What are the cultural differences seen in modern day Malaysian wedding cards?

2. What are the language variations projected in modern day Malaysian wedding cards? 


\section{VITALITY OF LANGUAGE AND CULTURE IN MALAYSIAN WEDDING CARDS: A MULTIETHNIC PERSPECTIVE}

\section{The need for wedding cards}

According to the wordnik dictionary (https://www.wordnik.com/words/wedding-cards), a wedding card is an invitation or notification sent out on the occasion of a marriage. Many communities still practice this tradition of a marriage celebration although how cards are designed and interpreted may depend on culture and personal desires.

Clynes and Henry (2004) studied Brunei Malay wedding invitations as a way of determining to what extent Bruneian students in a tertiary context were able to identify and explain the linguistic features of the Brunei Malay wedding invitation. They conclude that while the students were able to accurately describe the surface linguistic features of the genre, the students were less successful at explaining the use of these features in terms of the communicative purposes of the genre. The authors thus, conclude that Malay wedding invitations reflect the complexity of the wedding ceremony itself. They also mention that Malay wedding invitations can range from a simple A4 size card folded into three parts, to a folder containing up to six separate pieces of paper. The simpler three-part invitations are intended for non-family members who are invited only to the "bersanding" ceremonies while the more complex ones are meant for family members who are invited to all ceremonies. The overall communicative purpose of the invitation, as its name indicates, is to invite the receiver to attend the particular wedding ceremony detailed in the invitation. The authors also state that various elements in the invitation were designed to maximise the possibility that the recipient will actually attend, given that the attendance of the wider community is a crucial element.

In another context, Momani and Al-Refaei (2010) investigated the generic structure of Jordanian wedding cards. Adapting Holme's (1997) and Clynes and Henry's (2004) model for analysis, they aim to understand what components were employed to articulate the communicative purpose of these invitations. Focusing on the relationship between language and cultural representations within the discourse set in wedding invitations, they indicate that its genre revolved around six obligatory and two optional moves which reflect the socio-cultural values of the Jordanian society.

Another study conducted by Mirzaeli and Eslami (2013) focussed on wedding invitations too but their perspective include looking at the discourse and social variability evident in wedding invitation texts. Their findings suggest that besides religion, other sociocultural emerging factors such as (tertiary) education, feminism, socioeconomic status, profession, and age have massively impacted the young couples' preference for a certain type of wedding invitation but this preference is still prefabricated although the discourse may be modern. They also mention that more importantly, modern couples have created various discursive practices so as to preserve their own interests which are largely inspired by the newly emerging societal influences of the world or their own agendas. The findings of the study done by Mirzaeli and Eslami (2013) suggest that with time, the sociocultural aspects of life can influence the communicative behaviour of young people, and in this case, Iranian youths. Their study provides insight into the innovative wedding invitation texts of Iran which show that the contents of such wedding invitations are largely shaped by sociocultural beliefs and values.

Salwameh (2014) also looks at the generic structure of Muslim and Christian wedding invitations in Jordan. Like the others, he too focussed on the sociolinguistic aspect. He also agrees that these wedding cards were largely influenced by a number of factors encompassing social, economic and religious factors. He claims that his findings can enable sociolinguists to be better inforned of a society's social cultural norms and values. Nonetheless, it is inevitable that the exposure one gets can affect how one thinks thus, globalisation may have contributed to these changes over time. 


\section{VITALITY OF LANGUAGE AND CULTURE IN MALAYSIAN WEDDING CARDS: A MULTIETHNIC PERSPECTIVE}

In another study, Sadri (2014) studied Iranian wedding cards. He focussed on two areas of genre knowledge (i.e., form and content) and he aims to understand how this could have changed over time as a result of sociocultural forces. Focusing on 100 Iranian wedding invitation cards dating back to the 1970s until the present time, Sadri (2014) notes that the mode of contents contained in those cards he analyzed seems to have undergone changes over a period of time. However, he also notes that the generic structures shown in these cards have remained intact. Sadri (2014) also mentions that the changes noted in the contents of the card include the use of nonverbal features like shape or size, design and typography. He also notes that there were other verbal features encompassing text length, formality, reference terms and mood. Nonetheless, Sadri (2014) did not provide details on what is meant by verbal or non-verbal features or even the concept of typography. Thus, one has to make deductions based on one's prior knowledge of wedding cards. According to Sadri (2014), his findings imply that in today's sociocultural climate of Iran, "creativity prevails over conventionalization, informality is favored over formality, and solidarity tends to replace power in the hierarchical dimensions of gender differentials and parental domination" (Sadri 2014, p. 92). From this, it can thus be concluded that modern wedding cards are likely to have evolved and that they could contain and illustrate more creativity or differences when compared to past designs.

As a historian of Indian culture, Arundhati Virmani (2013) who had scheduled a talk on Indian wedding cards in 2013 in Malaysia, mentions that wedding invitations do not have a long history in India. He suggests that wedding invitations had emerged during the early 20th century and this was due to the adoption made by Indian princes and other urban elites. Over the years, wedding invitations became a norm and today, wedding invitations, thereby wedding cards, serve to portray the social identity and status of the Indian society. Arundhati Virmani (2013) also adds that wedding invitations which are printed in seedy shops in narrow gulis, or city backstreets of India, has today become a designer's item and a central part of the wedding ceremony of the Indian culture. Arundhati Virmani's talk was aimed at examining wedding cards as an element of the material culture of the elite. He further claims that wedding cards may also function as a bridge between the intimate and the social world, linking the close and not so close circles among human beings. Arundhati Virmani (2013) was targeting on exploring the more recent developments in the life of these objects and their implications for the Indian social 'communication system' today.

Nawaz, Plocher, Clemmensen, Qu, and Sun (2007) also focused on cultural differences between Denmark and China. Looking at wedding invitations, they were trying to locate the differences between the Danes and Chinese in grouping objects, functions and concepts into categories. Based on their study, one of their assertions made was that "Images are the visual language of a culture" (2007, p.16) and that "what we recognize in our culture may have little or no meaning in another" $(2007, \mathrm{p} .16)$ implying that there are specific differences for specific communities which are insignificant to others. Thus, there is a need to conduct more studies to gain better understanding of other cultures.

In the context of this paper, it is apt to state that the analysis of the wedding cards is based on how the locals comprising Malay, Chinese and Indian individuals would view these wedding invitation cards. In this regard, the analysis is not based on any previous literature studying cultural artifacts and their symbolisms but based on our respective cultural backgrounds as Malaysian Malay, Malaysian Chinese and Malaysian Indian. This limitation may thus make our analysis subjective but we based our analysis on other cultural experts who have a better knowledge on what the earlier communities were like and what were important for them. Thus, we make no claim of what is acceptable or unacceptable in the Malaysian society in terms of wedding card visuals and language except for our intention to show what is seen in the concept of "vitality" and "culture" that was etched onto wedding cards. For this purpose, a section explaining the importanc eof identity and culture in ceremomnies is proivded. 


\section{VITALITY OF LANGUAGE AND CULTURE IN MALAYSIAN WEDDING CARDS: A MULTIETHNIC PERSPECTIVE}

\section{Importance of identity and culture in ceremonies}

Culture is integral to mankind and every ethnic group embraces its own culture while its members are bound by sociocultural ties with one another through similarities in the language they speak, the beliefs they follow, the festivals they celebrate, the life-styles they practice, the principles they uphold, and so on (Turiel, 2002). It is also inevitable that those who belong to the same cultural descent may also agree on most social mores (Turiel, 2002) as each individual's practice enforces the tradition even more. Cultural similarity provides its members with a sense of attachment and togetherness at the personal, familial, communal and social level and this is important for any community as it provides a sense of belonging that is vital for survival. Of the many traditions and cultural practices that highlight significance of culture, marriage is one of them (Turiel, 2002).

In all world cultures and human societies, wedding ceremonies conform to essential principles comprising various rituals and customs which hold deep meaning for its participants (Holmberg, 1993). Though diverse in its forms and manner of solemnization, wedding events and preparations uphold conjugal practices and traditions that serve as identity of a particular group of people or ethnic who prescribe to the same cultural beliefs and values (Holmberg, 1993). Fisch (2001) adds that the kind of attention members of a community attach to certain aesthetic details of a culture, from the classic hymns to the clothing and conventional and customs and practices suggest that the central core of any ritual created in such practices is to persuade its members its significance and the more members adhere to the practice, the more power and importance such practices garner. This eventually makes the community assume such practices as mandatory and when operated by the respective individuals they become even more significant. Moving away from such practices make the respective member 'unconventional' and different, something which certain individuals may conform to. In this regard, though wedding may comprise mainly of individuals who may come from the same or different ethnic groups, every ethnic community tries to ensure that most, if not all, aspects of the wedding can reflect his/her or their cultural identity. This includes the symbols and images noted in wedding cards, which is the focus of this study. As cultural identities are built upon and shaped by multiple narratives from the past (Loseke, 2007), they speak of heritage inherited from forefathers which creates a sense of belonging and pride for individuals in a culture. In that regard, wedding ceremonies allow us to catch glimpses of past beliefs and customs, and to bridge the past and present, ensuring that family name and tradition is handed down to the next generation (Maruschak, 1985; Fern, 2013).

Religious significance is observed in almost all ethnic cultural rituals, where "the religion postulates by what causal means a ritual, if properly performed, should bring about the desired results" (Moore \& Myerhoff, 1977, p. 12). According to Moore and Myerhoff (1977), the interrelation between religion and religious ritual is conscious, explicit, stated and worked out. Cultural practice and tradition are highly valued especially in communities that give credence to religious doctrines and spiritual beliefs. He also says that most people find satisfaction in having performed those rituals as a religious duty but this is in actual weddings. Sengupta (1965) notes that "In every phase of the marriage ceremonial, all the acts, even the most insignificant are for auspicious and bright future and at every step gods are invoked and evil spirits dispersed, indicating the growing influence of magic" (p. 31). This, however, does not mean that anyone who observes a cultural marriage is religious or pious. Nonetheless, cultural beliefs and religion do influence the families involved. For instance, Western influence have created the practice of cake cutting and wine toasting in Malaysian wedding functions but still, their respective religious and cultural rites, rituals and symbolisms are preserved. Thus, culture and tradition hold great importance in wedding ceremonies.

In Malaysia, the impact that culture has on marriage constitution is visible as traditional marriages are still the most preferred by today's generation despite changes in sociocultural set up and upbringing 


\section{VITALITY OF LANGUAGE AND CULTURE IN MALAYSIAN WEDDING CARDS: A MULTIETHNIC PERSPECTIVE}

over the years. Though traditional customs have been adapted gradually to suit the culture of each successive generation (Maruschak, 1985), the primary features and characteristics of ethnic cultural wedding is nevertheless preserved. Apart from creating a sense of identity and belonging, being attached to a particular culture and participating in its ceremonies gives the satisfaction of having performed religious duties as cultural ritual and practices are often based on religious beliefs. Furthermore, culture influences one's choice of soulmate where selecting a future bride or groom from the same culture is believed to promote happiness and marital bliss as both individuals share the similar cultural mindset and conduct.

\section{Methodology}

This section discusses how data were sourced, classified and analysed. The terms used in this paper are further clarified.

\section{a. Culture}

Culture can be defined in various ways. For instance, it can refer to the cumulative deposit of knowledge experience, beliefs, values, attitudes, meanings, hierarchies, religion, notions of time, roles, spatial relations, concepts of the universe, and material objects and possessions acquired by a group of people in the course of generations through individual and group striving. It can also refer to the systems of knowledge shared by a relatively large group of people (https://www.tamu.edu/faculty/choudhury/culture.html). For the purpose of consistency and clarity, we treat the term culture as a way of life seen to be practiced by a group of people and this includes their behaviors, beliefs, values, and symbols that they accept, generally without thinking about them, and that are passed along by communication and imitation from one generation to the next. Culture is reflected in language and language use reflects culture. Occasionally, words may not be needed to portray culture because visuals, symbols, colours can also project culture. For example, the Malay culture in Malaysia is reflected by its symbolic crescent which represents Islam whereas for the Chinese red is definitive of its culture. Among the Indians, the myriad of colours used in their festivals reflect their culture.

Culture evolves over the years but it can be seen as a particular society's way of life dictated by the ideas, customs, and social behaviour of that society. In the context of this paper, culture thus refers to the various colours, icons of symbolic meanings and also the peculiar way each ethnic group conveys its meaning without words, in Sadri's (2014) words, the non-verbal aspects of the wedding card contents.

\section{b. Language}

Language refers to the system of words or signs that people use to express thoughts and feelings to each other. Language can also be any one of the systems of human language that are used and understood by a particular group of people encompassing words of a particular kind (http://www.merriamwebster.com/dictionary/language). In the context of this paper, language is defined as a communication system used by a particular community in a particular country .People use language to convey meanings and in the context of this paper, written language is applied in the wedding cards to convey certain messages.

\section{c. Vitality}

Vitality refers to the state of being strong and active; energy and changes that will give renewed vitality (http://www.dictionary.com/browse/vitality). In the context of this paper, the term is taken to mean 


\section{VITALITY OF LANGUAGE AND CULTURE IN MALAYSIAN WEDDING CARDS: A MULTIETHNIC PERSPECTIVE}

vibrancy and in our analysis, how the wedding cards demonstrate the exuberance or high spiritedness of its culture through the mixture of symbolic icons and language and designs.

\section{d. Wedding cards}

According to the Wikipedia, commercially printed 'fine wedding stationery' can be traced to the period immediately following World War II after which democracy and rapid industrial growth enabled the man on the street to mimic the life-styles and materialism of society's elite. The popularity of using wedding invitations was also heightened by the invention of thermography which allowed printing cards to be embossed. Then the invention of letterpress printing increased the use of wedding invitations which made headway when lasers were invented and so on. In the context of this paper, we define wedding cards as specially designed cards which are ordered by certain families for the purpose of being sent out as wedding invitations to friends, members of the family and outsiders. Usually, wedding cards are seen as a way of encouraging the invited guests to participate in the celebration of two individuals joining as one through faith, vows and promises.

It is observed that wedding cards, as invitations, have become a commercialized item and printing them can cost money and time. People who design wedding cards also want their own creation to be unique because wedding cards represent creativity which invitees may hold dear as a memory. Wedding cards, when properly scrutinized, can also project the social status of the host/hostess inviting. A richly embossed wedding card which is printed on extremely good paper is viewed differently from one that is printed on cheap paper because it professes the social status of the invitee. Wedding cards may also be printed in various materials and colours to match today's globalized world and modernity. Wedding cards can also denote one's social status through the design, materials used and probably the size of the cards.

\section{Limitation of paper}

This paper is exploratory in nature as it attempts to showcase some similarities and differences found in the wedding cards of the three dominant ethnic communities in Malaysia. Consequently, the findings may only reflect the vitality of respective communities in the Asian context.

For the purpose of this paper, a total of thirty wedding cards which had been currently used by the Malaysian community were used as the source of our data. These wedding cards are modern ones and they were compiled within the year of 2013 to 2014. Ten cards from each ethnic groups were chosen as a way of representing the ethnic groups of the Malays, Chinese and Indian community. For this paper, we used hard copies of the wedding invitation cards which were sourced from personal collections, friends, relatives and contacts who had been invited to recent weddings. To make up for the number we also accessed e-invitation cards sent by friends and students.

The cards were first classified according to the ethnic groups. They were then coded in terms of visuals or symbolic icons which we detected within the wedding cards. All these were then pulled out one by one and analysed for their meanings and connotations. This procedure was initiated by our personal understanding of the respective culture because the two researchers involved were from the Malay and Chinese community respectively. For the Indian perspective, we recruited the help of a few Indian individuals to help us verfiy our analysis. During the analysis stage, vague elements seen in the wedding cards which we found difficult to define, were given to experts such as those who were deemed as being more knowledgeable of the culture. In this case, priests and teachers of the respetive languages. Their opinions were consulted in terms of the intepretations of certain symbolic icons. We also consulted three other individuals to validate our findings. Contacts who had given us the wedding cards also referred us to some designers who were sought for their views about the purpose of 


\section{VITALITY OF LANGUAGE AND CULTURE IN MALAYSIAN WEDDING CARDS: A MULTIETHNIC PERSPECTIVE}

portraying certain symbols within the wedding cards. This was to further verify and validate our findings.

The thirty cards were then analysed in detail one by one, first to locate elements of commonality. This was processed by studying the icons and symbolic artefacts. The various visuals present on the outside and inside of the cards were scrutinized. We specifically tried to look for the major symbols which we expected to depict happiness or bliss. Then we focused on the common artefacts, and a number of objects before moving to colours, prayers and finally the language. In language, we also searched for specific expressions provided.

To develop the meanings depicted in the wedding cards, Leech's (1991) seven categories of meanings were used to categorize our data into groups. In our pioneer attempt using Leech's framework, it was found that the categories overlapped in terms of what we see in the wedding cards. Consequently, we merged two of Leech's categories into one as is illustrated below.

\section{Leech's Categories of Analysis:}

1. Conceptual meaning

2. Collocative meaning

3. Thematic meaning

4. Social meaning

5. Affective \& Connotative meaning

6. Reflected and Connotative meaning

\section{Findings}

In this section, we also provide samples to illustrate the wedding cards used for analysis. They are provided below with the first sample being a Malay wedding card, followed by a Chinese wedding card then an Indian wedding card. 


\section{VITALITY OF LANGUAGE AND CULTURE IN MALAYSIAN WEDDING CARDS: A \\ MULTIETHNIC PERSPECTIVE}
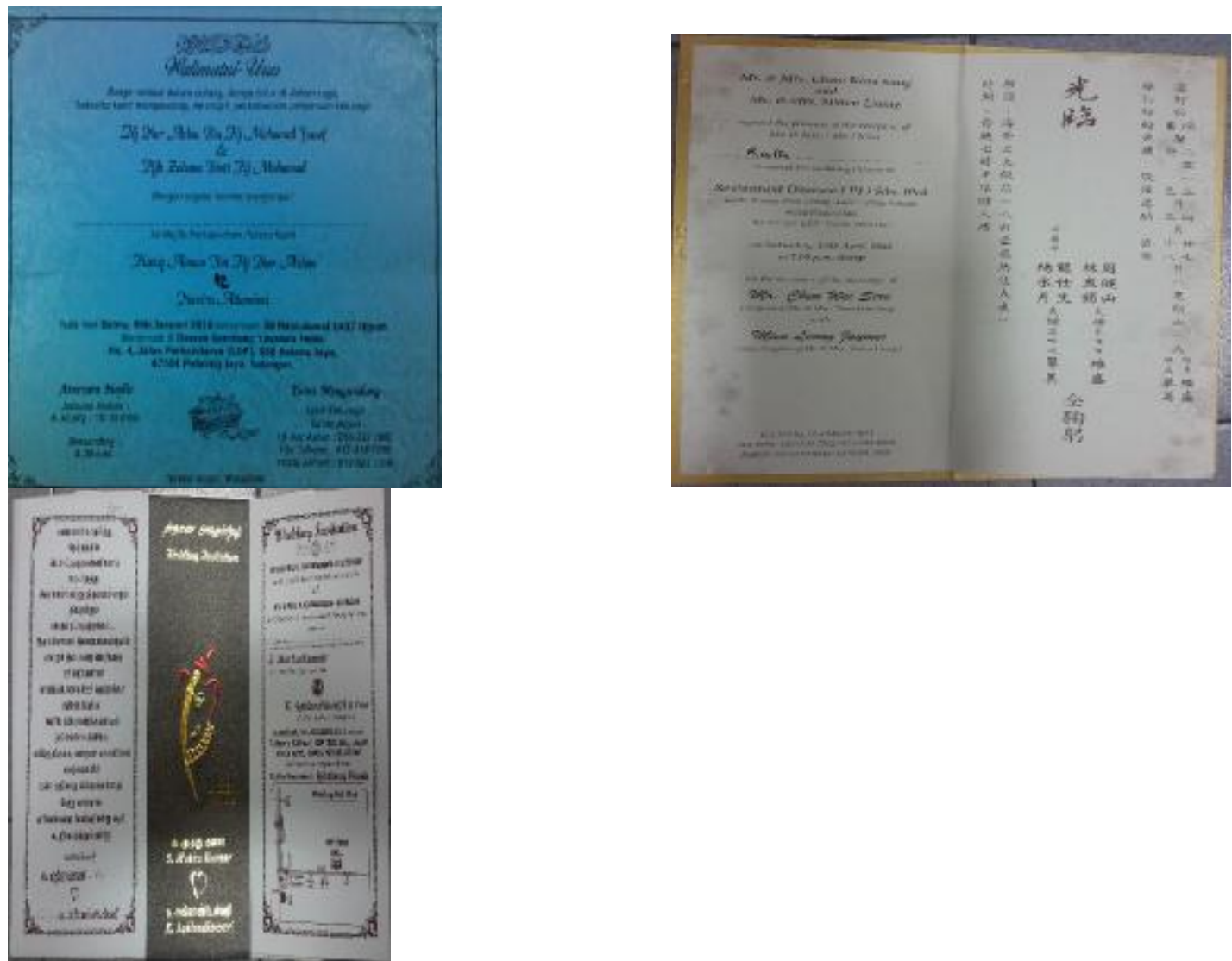

Although our data were diverse because the contents of the 30 wedding cards comprise of many elements, we decided to focus on what can be retrieved to be categorised under Leech's framework. Some examples extracted from the wedding cards are provided to support our claim. These were then placed according to the categories.

\section{Conceptual Meaning:}

This expression means a direct reflection / meaning of what we see (denotative meaning). In this category we tried to detect from the contents to see how the cards differ in terms of mentioning the number in birth of their child getting married. We also attempted to see if there were specific words used as a reference to the betrothed.

\begin{tabular}{|l|l|l|}
\hline Malay wedding cards & Chinese wedding cards & Indian wedding cards \\
\hline Use words : & Use words : & Use words : \\
Putra, puteri, anakanda & Eldest son/daughter & Son/daughter of \\
(Translation: prince, princess, child) & Youngest son/daughter & \\
& Only son/daughter & \\
\hline
\end{tabular}

As can be noted, the three ethnic groups differ in how they mention the name or the child to be married. In the Malay wedding card. According to the Malay culture, the specific term used to address the person about to be married was depicted as 'younger' thus in Malay as prince (male) or princess (female). This is probably because the recipients of the cards would be older people within the same age range of the 


\section{VITALITY OF LANGUAGE AND CULTURE IN MALAYSIAN WEDDING CARDS: A MULTIETHNIC PERSPECTIVE}

parents, who are presumably, issuing the wedding cards. Experts in the Malay culture also informed that those who are to be married are often treated as "Raja sehari" or "King of the day" hence, it is possible that the terms prince/princess in Malay was used as a way to reflect the younger person, de monstrating a subtle and formal language use. It was noted that the names of the invitees that is the names of the parents would be stated more visibly on the wedding cards before it is followed by "prince" or "princess' and then the names of the couple who are to be married.

In the case of the Chinese wedding cards, it was noted that there was no special term used depicting as 'King" or "prince" but the Chinese culture does indicate the name of the couple who were to be married. This would be preceeded by the mention of the birth position of the child for example, first born, second born or youngest child. In order to denote who had issued the wedding card, the invitation would also use the term 'ling lang' or 'ling jun' to depict whether it is the son or daughter who is getting married and the name of the parents of the othe party is often also mentioned. In the Chinese wedding card, the family issuing the card, thus the host, often has the names mentioned first. This is how Chinese families are able to differentiate who is hosting the wedding lunch or dinner.

In the case of the Indian community, the card would contain the name of the invitees (host) most visibly i.e. their names come before the names of the couple to be married. Unlike the Chinese, Indian wedding cards do not mention the birth position of the child getting married. Sometimes, it might be difficult which one of the couple is the child of the invitees. However, as in the Malaysian context, one way to locate this is to examine the name of one of the couples getting married. The name would carry a first name followed by 'the son of' or 'the daughter of' so and so (usually the father's first name). In the Indian culture, the use of 'son of' or 'daughter of' is to show the family connection. In Malaysia, the Malay and Indian communities do not use surnames like the Chinese community does. Thus, providing the term 'son of' or 'daughter of' is a reasonable explanation to the receipient of the wedding card. Our cultural expert says that this has always been the tradition for the three respective communities but our claims cannot be verified with documentations as we could not really locate any historical descriptions. These findings agree with Salwameh (2014) which states that wedding cards were largely influenced by social cultural norms and values.

\section{Collocative Meaning}

This term implies that meanings are perceived through what has been communicated through association with words which also tend to reflect the event.

\begin{tabular}{|l|l|l|}
\hline Malay wedding cards & Chinese wedding cards & Indian wedding cards \\
\hline Walimatul urus & shuangxi or $x i$ & $\begin{array}{l}\text { Picture of Hindu maharaja, } \\
\text { (shown as picture of elephant's }\end{array}$ \\
$\begin{array}{l}\text { Translation:.........) } \\
\text { Written in Roman and or Arabic } \\
\text { alphabets. }\end{array}$ & $\begin{array}{l}\text { (Translation: double happiness or } \\
\text { happiness) written in Chinese } \\
\text { characters or as a logo. }\end{array}$ & \\
\hline
\end{tabular}
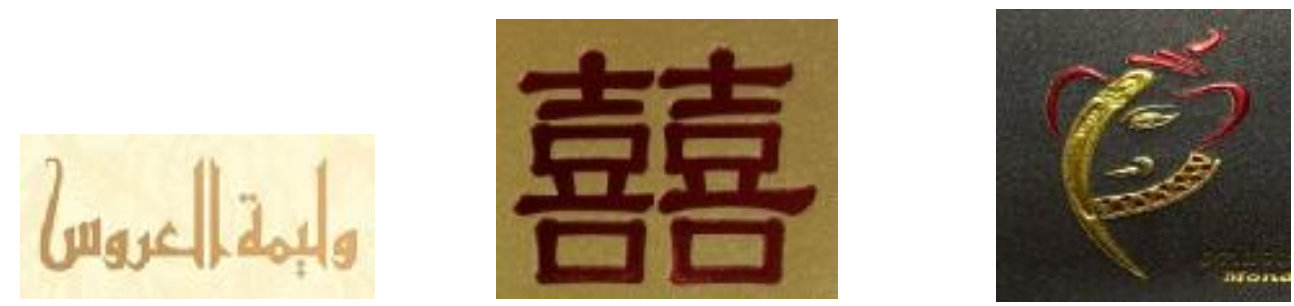


\section{VITALITY OF LANGUAGE AND CULTURE IN MALAYSIAN WEDDING CARDS: A MULTIETHNIC PERSPECTIVE}

As the limited data illustrate, it was noted that all the Malay wedding cards were printed with the term "walimatul urus" printed in Arabic which means "Wedding Reception". This is probably because it is an essential item to preserve in a wedding invitation as it is the main purpose of the wedding card. It is noted only in the wedding cards of Malaysian Malays who are all Muslims.

In the Chinese wedding card, it was noted that the icon "shuangxi" or "xi" which means happiness, like the Malay term above, was an important and necessary item to print. It is tied to the Chinese culture and also belief. The term denotes double happiness and it connotes eternal happiness for both parties, thus, the twin word.

In the Indian wedding cards, connotations of Hinduism was reflected in the icon of a Hindu king (maharaja), elephant or parts of an elephant like a tusk or peacock or even the silhouette of an Indian priest or some kind of Indian feature that is visibly clear for example a sari-clad female figure. There was no commonly used term identified in the Indian wedding cards. Thus, it is deduced that despite the absence of words to display the Indian religious belief, the symbolisms applied within the wedding cards were quite emphatic. Clynes and Henry (2004) also suggested that invitations reflect the complexity of the wedding ceremony itself.

\section{Thematic meaning}

This category refers to the message being organized in terms of order, focus and emphasis of the event.

\begin{tabular}{|l|l|l|}
\hline Malay wedding cards & Chinese wedding cards & Indian wedding cards \\
\hline Title : & Title: & Title : \\
Eg. 'Perutusan Raja Sehari' & Eg. Wedding invitation were & Eg. Wedding invitation written in \\
(Translation: Order of the King of & written in Mandarin and English. & English and or Tamil \\
the Day) & & \\
$\begin{array}{l}\text { Jemputan Majlis perkahwinan } \\
\text { (Invitation to wedding reception) }\end{array}$ & & \\
$\begin{array}{l}\text { Kisah cinta kita majlis resepsi' } \\
\text { (Wedding reception of our love } \\
\text { story) }\end{array}$ & & \\
\hline
\end{tabular}

$$
\text { Pe, }
$$

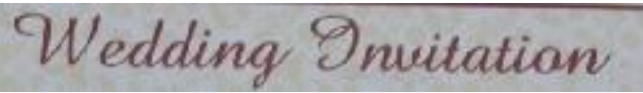

In the data presented above, it is clear that each ethnic community has its own way of reflecting its culture. In the Malay wedding cards, terms commonly used were "Special terms" used by a bride and bridegroom and in the Malay culture it includes terms like :perutusan Raja sehari" which means "the command of the King for the day". Other linked terms were "Jemputan Majlis perkahwinan" which means "invitation to a wedding reception" and the other term commonly used was "kisah cinta kita", and "majlis resepsi" which means "our love story" and "reception" respectively. It was noted that the wedding cards we analysed were monolingually written in Malay with interspersed phrases of Arabic as preferred by the religion of Islam. There was no translated version in English or Arabic.

From the analysis of the Chinese wedding cards, it was noted that the wedding invitation was quite clearly reflected in the written character in Mandarin which says " $x i$ jiu" a term which tells every reader it is a wedding invitation. The term actually means 'blissful wine or liquor' but not all Chinese weddings serve wine and liquor although most do. It also appears that the wedding card could be written in two languages Mandarin and English. Thus, bilingual cards seemed to be a common feature in all of the wedding cards we analysed. This is probably because the invitees (hosts) include those who can 


\section{VITALITY OF LANGUAGE AND CULTURE IN MALAYSIAN WEDDING CARDS: A MULTIETHNIC PERSPECTIVE}

read Chinese characters as well as those who cannot, thus English was also provided as a means to complete the information.

In the Indian culture, the term wedding invitation was also noted to be written in both Tamil and English. Like the Chinese wedding cards, it is assumed that the bilingual card was created for the benefit of non-Tamil speaking or reading guests.

\section{Social Meaning:}

This category refers to what is communicated of the social circumstances of the language use (convey social interaction)

\begin{tabular}{|c|c|c|}
\hline Malay wedding cards & Chinese wedding cards & Indian wedding cards \\
\hline Date (Islamic lunar calendar) & Date (lunar calendar) & Date (lunar calendar) \\
\hline Time & Time & Time \\
\hline Parent's names & Parents' names & Parents names \\
\hline Venue/place of reception & Venue/place for reception/dinner & Venue place of wedding and or \\
\hline Name \& telephone number to & & Map \\
\hline contact & & Names and telephone number to \\
\hline Modern: & Modern: & \\
\hline RSVP & Theme (eg,same colour) & Modern: \\
\hline Reply via FB & RSVP & RSVP \\
\hline (all were written in Malay) & Time e.g. $6.00 \mathrm{pm}$ sharp & Bus service \\
\hline & $\begin{array}{l}\text { Information was in Mandarin and } \\
\text { English }\end{array}$ & $\begin{array}{l}\text { Important information was } \\
\text { indicated in Tamil and English. }\end{array}$ \\
\hline
\end{tabular}

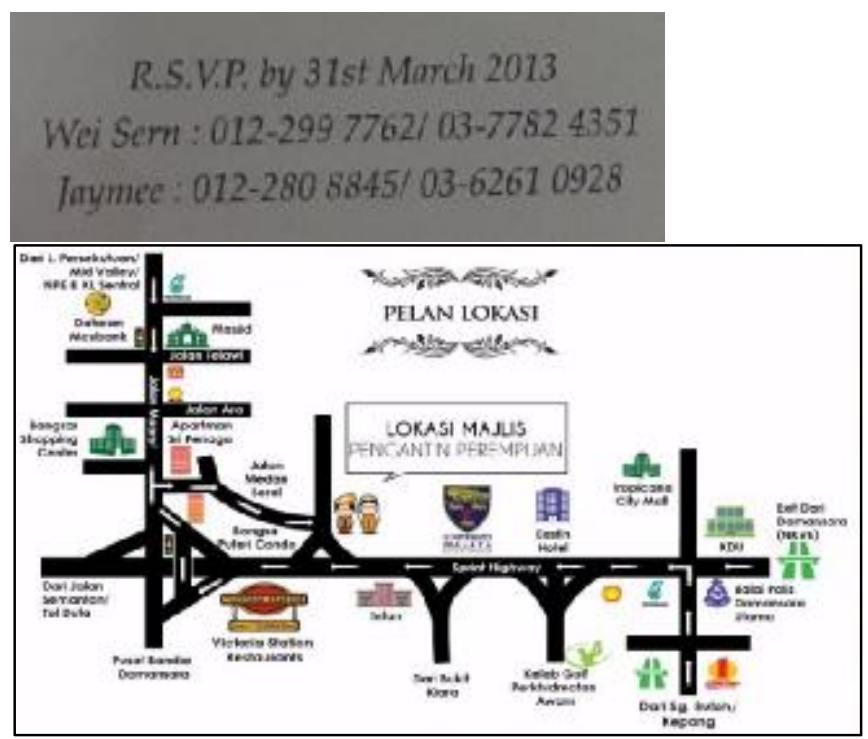

Data show that the social aspect of a wedding cannot be divorced from a wedding invitation card because such information is vital. By social aspect, it is meant other informative factors like time, place, venue (and how to get there) and most particularly, most wedding cards today, actually provide a GPS map. This element of the social aspect is present in all the three ethnic groups' wedding cards where 


\section{VITALITY OF LANGUAGE AND CULTURE IN MALAYSIAN WEDDING CARDS: A MULTIETHNIC PERSPECTIVE}

the necessary information of where, when and how are provided. In addition, it was noted that the western concept of RSVP (Répondez s'il vous plait) which, in the context of social invitations, is a request for a response from the invited person or people which also means "Reply if you please" or "Reply please". Many years ago, this aspect of social manners was considered rude, according to experts but today it is vital information as it costs money to make arrangements for food, thus responses would be a better gauge to save money and not waste. From the analysis, it is noted that modern Malaysian wedding cards tend to contain the acronym of RSVP. This, it is deduced, is linked to the modern lifestyle of today where globalisation and practicality makes it necessary to insert such an element into wedding cards.

In the Malay wedding card, it was found that modern technology can also play a vital role in changing the design of the wedding card. For instance, replies to or not to attend weddings was requested via Facebook (FB).This exception was attributed to the vast use of social media. Nonetheless, some also inserted private mobile number for contacts.

In the Chinese wedding card, it was noted that 'themes' common in the western culture had been included as a change to the wedding card. Some themes encompass colour of attire for the ceremony, formal dress-code and others.

Noting this as a form of creativity and modernisation, it appears that changes would not be too diverse from traditional ones. It was noted from our analysis that the changes include adding photos of the couple, colours to the card, and possibly the texture of the envelope which can be embossed. Other than that, the traditional elements remained. This creativity and modernisation is attributed to globalisation and exposure to new cultures. It is also deduced that when wedding cards deviate from the old traditional ones in terms of visuals like dragon or phoenix, or in terms of red and pink and so on, the change could highlight that the host/hostess is educated or is knowledgeable about current practices. To some extent, it denotes that some people still like to maintain a certain status in a nonverbal way.

In the Indian wedding card, analysis shows that not only was the western practice of RSVP present in most of the wedding cards, it was also visibly clear that the invitees or host provided additional information for guests within the wedding card. In this regard, it includes information to transportation for guests or attendees.

\section{Affective \& Connotative Meaning}

This category refers to what is being communicated via the feelings and attitudes of the sender. In the context of the wedding card, this analysis can only be extracted by studying the content more deeply. A linguistic perspective followed by a visual perspective was thus applied.

\begin{tabular}{|l|l|l|}
\hline Malay wedding card & Chinese wedding card & Indian wedding card \\
\hline Agenda (with time) & A pair of birds & Décor of mango , peacock feathers, \\
Love or heart shape & Ring & Lehphant's trunk \\
A pair of birds & Love or heart shape & Colour - mart shape \\
Flowers, leaves, trees (nature) & Flowers & or cards \\
Image of couple or picture of the & Image of couple or picture of bride \\
bride and groom & and groom & Picture of women \\
Ring & Red, pink or gold was used in the & Image of a couple \\
Colour ([pastel] & wedding card & Modern; \\
Modern: & & Poem and prayer wishes \\
\hline
\end{tabular}




\section{VITALITY OF LANGUAGE AND CULTURE IN MALAYSIAN WEDDING CARDS: A MULTIETHNIC PERSPECTIVE}

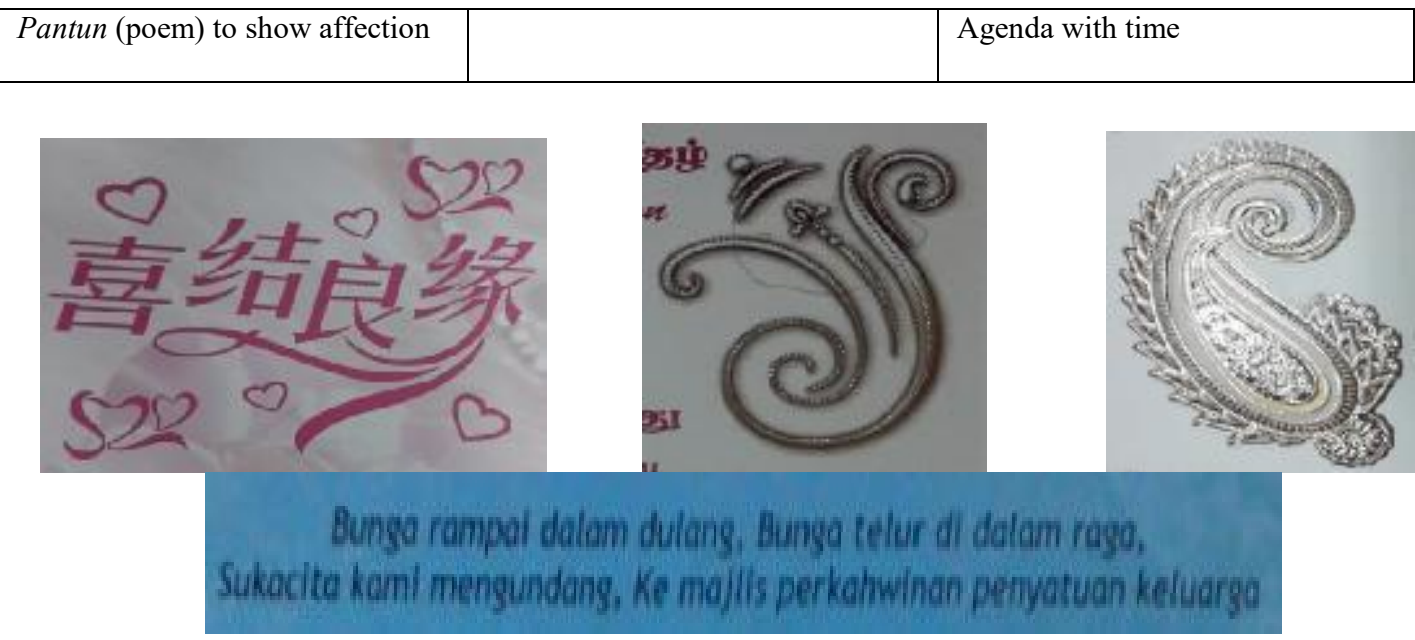

This category of the analysis was an interesting find because it was the part that reflected much of the respective ethnic groups' cultures.

In the Malay wedding cards, the symbol of a Malay wedding was depicted by a modern feature and in the wedding cards we analysed, the 'heart shape' featured in a few cards and it was followed by the symbol of 'love birds'. In other cards, we noted the elements drawn from nature such as flowers, leaves and trees. Although the symbolic meaning of nature is broad, it is observed that wedding cards used by the current Malaysian society even among Malays, who have always been said to be the most traditional (See Asri, 2003; Asmah Haji Omar, 2002) among the three ethnic groups also featured western symbols of love such as the one mentioned above. In addition, modernity also featured in Malay wedding cards through a photograph of the wedded couple and this was inserted into a corner or middle of the wedding card. However, not all the wedding cards carried a photograph. This occurrence of not using photographs is attributed to the cost of printing as it would have incurred more money in the printing of the cards (interview with printer). Another western concept of the wedding such as the symbol of the ring was also featured and it was followed by the use of pastel colours which probably, also connotes modernity. This is deduced from the comparison of other wedding cards which seemed to carry old and traditional colours such as white only. From this perspective, it was further noted that Malay wedding cards may also contain traditionalness of the Malay society which is depicted by a Malay pantun (poem) and as the nature of the wedding card suggest, it depicts affection of the couple who are inviting the guests or attendees to share in celebrating their union.

In the Chinese wedding card, it was also noted that a western concept of the pair of love bird was depicted together with the western symbolic concept of the 'ring' and 'heart shape'. Likewise, modernity also trailed via the photograph of the couple within the wedding invitation. It was further noted that traditional colours of bright red often used by traditional Chinese as a sign of auspiciousness which a wedding can highlight was not identified in any of the wedding cards analysed. In replacement, the colours were still maintained to be bright but in the case of this paper it was noted as maroon red, light pink and soft gold was used as the background of the wedding cards.

In the Indian wedding cards, it was noted that cultural aspects of Hinduism, a religion practised by Indians, was present within the wedding cards and this was displayed via the symbolic mango leave, representation of the mango tree, representation of the revered bird, a peacock was depicted. It appears that Indian myths and stories seem to have the peacock as a part of the story. It is deduced that this portrayal of Indian religious values helps to portray the Indian culture as intact. Nonetheless, it was 


\section{VITALITY OF LANGUAGE AND CULTURE IN MALAYSIAN WEDDING CARDS: A MULTIETHNIC PERSPECTIVE}

also interspersed with some degree of modernity which was reflected through the western symbolic concept of 'heart shape' followed by the visual image of a couple which could project a wedding as the couple drawn as silhouettes were also adorned. Interviews with Indian individuals suggest that the maroon colour portrayed by some Indian wedding cards could reflect the concept of mere individual taste but it could also be the Indian culture's preference for certain colours. In some of the wedding cards analysed it was noted that it also included a tradition of the Malay culture where a poem and prayer wishes were inserted. Both these elements did not appear in the Chinese wedding cards.

\section{Reflected and Connotative Meaning}

This category refers to what is communicated through association with another sense of the same expression. It refers to a person's actual experience. The association a person makes when he/she says or hears a word. In other words, it goes beyond the denotative meaning. Meaning in this category is unstable as it varies according to culture, time period, individual experience. The word "rose" for example has other characteristics other than what is mentioned in the dictionary. These could bring about positive or negative connotations. It could be an individual connotation or shared by a particular ethnic group.

\begin{tabular}{|l|l|l|}
\hline Malay wedding card & Chinese wedding card & Indian wedding card \\
\hline $\begin{array}{l}\text { Logography in Arabic alphabet } \\
\text { Pantun (poem) }\end{array}$ & $\begin{array}{l}\text { Logography in Mandarin } \\
\text { Colour is red, pink, and gold }\end{array}$ & Logography is in Tamil \\
Pepak sireh (tray for some & Peaco feathers \\
condiments) & Bamboo & Mango shape \\
Islamic calendar & & Elephant \\
Islamic greeting & Temple, priest \\
Doa (prayer) & Lotus, \\
Décor of songket and carving & Angel \\
Modern & Chariot \\
$\begin{array}{l}\text { Card reflects occupation for } \\
\text { example bank workers issued } \\
\text { wedding card as a cheque, a } \\
\text { boarding pass, an exam paper and } \\
\text { so on. }\end{array}$ & Hands \\
& Lamps \\
\hline
\end{tabular}
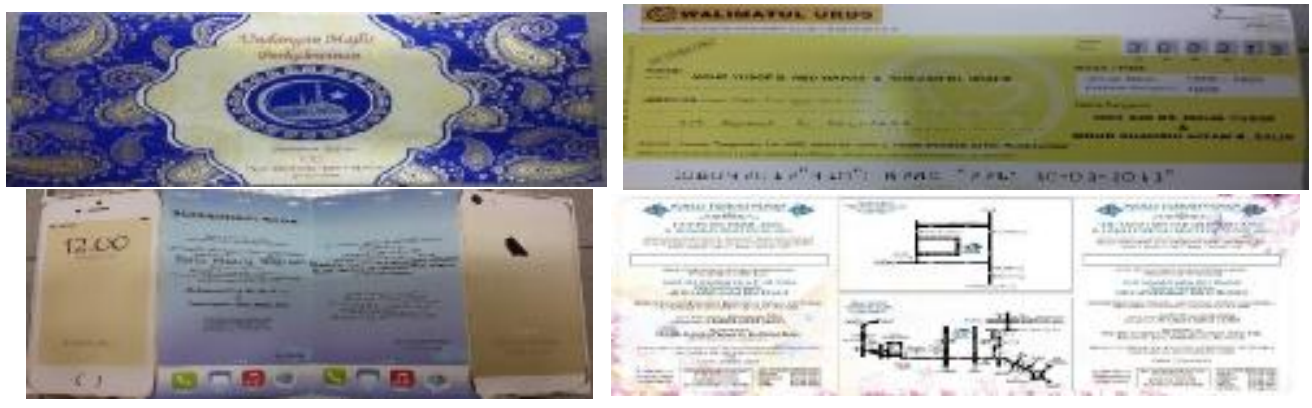

Data presented suggest that in the Malay wedding cards, culture and belief are important reflections. All Malays are Muslims, thus, the logography written in the Arabic alphabet, Islamic date, Islamic greeting and doa (prayers) were portrayed in and on the wedding cards. For a more traditional and cultural reflection, the pantun, was further displayed via the décor of the Malay traditional material, 


\section{VITALITY OF LANGUAGE AND CULTURE IN MALAYSIAN WEDDING CARDS: A MULTIETHNIC PERSPECTIVE}

songket and carving whilst the symbol of the tepak sireh may sometimes be shown on the cards. Sometimes other rhetorical and/or poetic languages (besides pantun) also appeared on the cards.

In the Chinese wedding cards, the logography was in Mandarin, accompanied by drawings of the bamboo (this seems to indicate Chineseness), the colour of the cards which would not deviate too far away from red, pink, orange, purplish and these too helped to portray the Chinese belief of what a wedding means and also the Chinese culture. In some wedding cards, poetic language, like a short poem, also appeared on the cards. Generally, only those well versed in the Chinese language and culture would do this. Thus, indirectly, it also denotes the social status of the invitees/host.

As for the Indian wedding cards, significant items which reflect the Indian culture and beliefs were also noted in and on the cards. Since majority of the Indians are Hindus, features of Hinduism are likely to prevail and there were features such as a peacock feathers of the peacock, elephant, lotus and others were used as visuals. It was also noted that in some Indian wedding cards, a certain level of poetic language (like muuthurai) was also written on the cards.

\section{Discussion and Conclusion}

These findings suggest that in a mutliethnic society, even cultures could be influenced uncosnciosulsy where the impact of the western practices of the RSVP, love symbols of the love birds and wedding rings were found to be existing in modern Malaysian wedding cards. Further, it was noted that the time had also impose changes such as changing the colours of traditional wedding cards to more subtle colours or more modern and acceptable shapes and sizes or even adding photos of the couple inot wedding cards were being practised by the three ethnic groups in Malaysia. In other instances, it was also noted that technology may in some way influence the design or depitcion of modenr wedding cards such as requesting for replies from Facebook and mobile devices. Nonetheless, we noted that Indian wedding cards had not added a photograph of the couple.

It is further noted that despite the practice of modernity and applying western concepts within their wedding cards, a multiethnic society like Malaysia is not to be outrun by modernity because as was noted, much of the traditional aspects of the three ethnic groups in terms of cultures and beleifs seem to persist in the wedding cards analysed. It was also noted that the Malays adhered to some practices possibly demanded by its relgious beliefs and values where an Arabic phrase was present in all the wedding cards. In the Chinese community, it was noted that the Chinese element of 'shuangxi' or ' $x$ ' is inevitable and has to be imprinted in all the wedding cards. As for the Indian wedding cards, some aspect of the religious beliefs depicted by specific symbols were present.

Moreover, modern or present day wedding cards of the Malays accommodated a balance of modern and traditional concepts such as pictures of mobile phone, aeroplane, boading tickets, and many others. These changes attributed to modenrity, seem to imply that among the three ethnic groups, the Malays could still be more tradtional than the others and yet more modern too. The Chinese, to some extent, were also considered traditional in how the information of the wedding invitations proceed in terms of names, number of child getting married to number of child of the other family. There was some balance of modernity being treated with either photographs of the couple of the change of the colour of the wedding invitation card. Interviews with three Chinese individuals indicated that the Chinese auspicious colours has to be bright and so one never receives a Chinese wedding invitation card that is white, black, green or blue no matter how 'educated' or 'modern' the family may be. As for the Indians, if they were not Hindus by religion, it appears that the Tamil logography still appears on the cards. If they were Muslims, they would probably adhere more to the Islamic way but this is yet to be further verified. 


\section{VITALITY OF LANGUAGE AND CULTURE IN MALAYSIAN WEDDING CARDS: A MULTIETHNIC PERSPECTIVE}

Aphek and Tobin (1989) states that the meanings of the cards may be seen as exhaustively classifying a larger thematic continuum if we view the "divinatory" meanings attached to each card as representing most, if not all, the possible semantic, cultural and social attributes of an umbrella term or theme related to that particular card (p. 138). Nonetheless, it cannot be denied that living in a multicultural society like Malaysia, the respective ethnic groups had somehow held on to their respective cultures and traditions. In some ways, there are positive benefits to be gained in that there is diversity to be enjoyed and discovered. The negative impact of this practice is that the multicultural society cannot merge to become one despite the call by the government to be as one. More studies need to be conducted to evaluate the extent of this diversity.

\section{References}

Al Momani, Kawakib Radwan; Alrefae, Dana Faisal. (2010). A Socio -Textual Analysis of Written Wedding Invitation in Jordanian Society. LSWP Professional Communication Knowledge Cognition Management 1(1).

Apeh,E. and Tobin,Y (1989).Semiotics of Fortune Telling, Amsterdam \& Philadelphia: John Benjamins

Arundhati Virmani, Indian Wedding Cards: Publicizing the Intimate. Centre Norbert Elias, École des Hautes Études en Sciences Sociales.

Asmah, Haji Omar. 1995. "Indirectness as a Rule of Speaking Among the Malays." In Rules of Speaking - Verbal Interactions at Play, edited by Z.A. Majid and L.M. Baskaran, 47-60. Petaling Jaya: Pelanduk.

Asmah Haji Omar. (1996). Budaya Dan Bahasa Kiasan . Dewan Siswa : Jilid Seminar Islam Hudharikefahaman mengenai keutuhan Budaya. Melaka (18-19)

Asrul, Zamani. (2003). The Ideal Malays. PJ: Golden Vision Publications.

Braithwaite, D. O., \& Baxter, L. A. (1995). I do'again: The relational dialectics of renewing marriage vows. Journal of Social and Personal Relationships, 12(2), 177-198.

Chesser, B. J. (1980). Analysis of wedding rituals: An attempt to make weddings more meaningful. Family Relations, 204-209.

Clynes, Adrian and Henry, Alan. (2004). Introducing Genre Analysis using Brunei Malay Wedding Invitation. Language Awareness. 13(4), 225-242.

Fern, E. G. C. C. (2013). Ancestor Power: Marriage rituals of a Hakka community in Sarawak, Malaysia. Malaysian Journal of Chinese Studies, 2(1), 35-47

Fisch, M. (2001). The Rise of the Chapel Wedding in Japan: Simulation and Performance. Japanese Journal of Religious Studies, 28(1/2), 57-76.

Holmes, J. (2013). An Introduction to Sociolinguistics ( $4^{\text {th }}$ edition). London: Routledge Publications.

Lee, S. M., \& Fernandez, M. (1998). Trends in Asian American racial/ethnic intermarriage: A comparison of 1980 and 1990 census data. Sociological Perspectives, 41(2), 323-342. 


\section{VITALITY OF LANGUAGE AND CULTURE IN MALAYSIAN WEDDING CARDS: A MULTIETHNIC PERSPECTIVE}

Leech. G. (1991) Semantic - A Study of Meaning. Retrieved from wyxyjpk.nankai.edu.cu/EnglishLanguageAndLiterature/.../8.pdf (20 May, 2013).

Löbner, S. (2013). Understanding Semantics.Routledge Taylor and Francis Group: London and New York.

Loseke, D. R. (2007). The study of identity as cultural, institutional, organizational, and personal narratives: Theoretical and empirical integrations. The Sociological Quarterly, 48(4), 661688.

Maruschak, L. A. (1985). The Ukrainian wedding: An examination of its rites, customs, and traditions.

Mirzaei, Azizullah; Eslami ,Zohreh (2013). Exploring the variability dynamics of wedding invitation discourse in Iran. Journal of Pragmatics, 55,103-118.

Moore, S. F., \& Myerhoff, B. G. (1977). Secular ritual. Uitgeverij Van Gorcum.

Muhammad Haji Salleh. (2002). Fungsi sastera dalam kehidupan masyarakat. Kuala Lumpur. Dewan Bahasa dan Pustaka.

Naylor, L. L. (1998). American culture: Myth and reality of a culture of diversity. Greenwood Publishing Group.

Nawaz, Ather; Plocher, Thomas; Clemmensen, Torkil; Qu, Weina; Sun, Xianghong. (2007). Cultural differences sin structure of categories in Denmark and China. Research, working paper. Frederiskberg.

Okamoto, D. G. (2007). Marrying out: A boundary approach to understanding the marital integration of Asian Americans. Social Science Research, 36(4), 1391-1414.

Philomin, L. (2016, August 19). When it comes to marriage and other personal issues, race matters. Retrieved September 11, 2016, from http://www.todayonline.com/singapore/sporeans-prefersomeone-same-race-personal-matters-survey

Qian, Z., Blair, S. L., \& Ruf, S. D. (2001). Asian American interracial and interethnic marriages: Differences by education and nativity. International Migration Review, 557-586.

Richards, I. A. (1967). The Philosophy Of Rhetoric. London: Oxford University Press.

Sadri, E. (2014). Iranian Wedding Invitations in the Shifting Sands of Time. RALs, 5(1), Spring 2014. 91-107

Salwameh, Murad (2014). A Sociolinguistics study of Muslim and Christian wedding Invitation Genre in the Jordanian society. Journal of Advances in Linguistics. 5(1), 449-462. Retrieved October 11, 2016 from https://www.academia.edu/8700585/A_Sociolinguistic_Study_of_Muslim_and_Christian_ Wedding_Invitation_Genre in the Jordanian_SocietyCouncil

Sakina Suffian (2000). Manusia Dan Alam Sebagai Medan Sumber Metafora Melayu: Satu Kajian Semantik. Disertasi, Fakulti Bahasa dan Linguistik: Universiti Malaya. 


\section{VITALITY OF LANGUAGE AND CULTURE IN MALAYSIAN WEDDING CARDS: A MULTIETHNIC PERSPECTIVE}

Sengupta, N. (1965). Evolution of Hindu Marriage: With Special Reference to Rituals, C. 1000 BC-A. Popular Prakashan.

Turiel, E. (2002). The culture of morality: Social development, context, and conflict. Cambridge University Press.

\section{Contact details of authors}

Ms Siti Rohana Binti Mohd Thani

Department of English Language

Faculty of Languages \& Linguistics

University of Malaya, 50603 Kuala Lumpur

Email: srohana@um.edu.my

Dr. Kuang Ching Hei

Department of English Language

Faculty of Languages \& Linguistics

University of Malaya, 50603 Kuala Lumpur

Email: kuangch@um.edu.my

\section{Biodata}

Siti Rohana Binti Mohd Thani holds an MA (TESL) from N. Arizona University, Flagstaff, USA. She is a lecturer at the department of English, Faculty of Languages \& Linguistics, University of Malaya. Her research interest is in the area of endangered languages and sociolinguistics

Kuang Ching Hei is currently associate professor at the Faculty of Languages \& Linguistics, University of Malaya. She is a certified teacher specialising in TESOL, holds a PhD in Sociolinguistics, a Master of Arts in English Language Teaching. She is a trainer and speaker for workshops organised by ADEC (Academic Development Centre, UM) focussing on Postgraduate Supervision, Coaching and Mentoring, Teaching and Learning (Building student rapport, Know your learners, Student centred learning, Learning assessment), and is a facilitator and trainer on Academic writing skills, Critical thinking skills, Qualitative research methods and Literature review for postgraduate students. 